\title{
Response of sunflower varieties to NPK fertilization
}

\author{
Ijaz Ahmad ${ }^{1}$, Sultan Akbar Jadoon ${ }^{1}$, Ahmad Said ${ }^{2}$, Muhammad Adnan ${ }^{3 *}$, \\ Fida Mohammad ${ }^{1}$ and Fazal Munsif ${ }^{4}$ \\ 1. Department of Plant Breeding and Genetics, the University of Agriculture, Peshawar-Pakistan \\ 2. Office of the assistant agronomist, Agriculture Research Institute, Tarnab, Peshawar-Pakistan \\ 3. Department of Agriculture, the University of Swabi-Pakistan \\ 4. Department of Agronomy, AMK campus Mardan, the University of Agriculture, Peshawar-Pakistan \\ *Corresponding author's email: madnanses@ gmail.com
}

Citation

Ijaz Ahmad, Sultan Akbar Jadoon, Ahmad Said, Muhammad Adnan, Fida Mohammad and Fazal Munsif. Response of sunflower varieties to NPK fertilization. Pure and Applied Biology. Vol. 6, Issue 1, pp272-277.

http://dx.doi.org/10.19045/bspab.2017.60024

\begin{tabular}{llll}
\hline \hline Received: 06/10/2016 & Revised: 07/02/2017 & Accepted: 16/02/2017 & Online First: 21/02/2017 \\
\hline
\end{tabular}

Abstract

This study was executed at Agriculture Research Institute (ARI) Tarnab (Peshawar) to evaluate the response of sunflower varieties (hybrids) to different combinations of Nitrogen, Phosphorus and Potash (NPK). Four sunflower varieties (hybrids i.e Aritar-93, Peshawar-93, Hysun-33 and SF-187) were sown with five levels of NPK (40:40:40, 80:50:50, 120:60:60, 160:70:70 and 200:80:80 $\mathrm{kg} \mathrm{ha}^{-1}$ ) using two factorial randomized complete block design with three replications. With the increase of NPK levels, significant increase for disc diameter (13\%), plant height (4\%), days to maturity (8\%), 1000 grain weight $(9 \%)$, biological yield $(20 \%)$ and grain yield (12\%) were recorded with the exception of filled grain head ${ }^{-1}$. Better performance was observed for 200-80-80 $\mathrm{kg} \mathrm{ha}^{-1}$ NPK than the rest of the fertilizer treatments. The interaction between fertilizers and varieties $(\mathrm{F} \times \mathrm{V})$ had non-significant effect on all parameters; however, varieties were significantly different from one another. Hybrids i.e SF-187 and Hysun-33 performed best among the four hybrids in all parameters with yield capacity of 1408 and $1267 \mathrm{~kg}_{\text {grain ha }}{ }^{-1}$ respectively. Thus it is suggested to apply NPK at the rate of $200-80-80 \mathrm{~kg} \mathrm{ha}^{-1}$ to hybrids SF187 and Hysun-33 for obtaining good yield of sun flower among the studied combinations.

Keywords: Grain yield; Hybrids; Nitrogen; Phosphrou; Potassium; Sunflower

\section{Introduction}

Sunflower (Helianthus annuus L.) belongs to the family Astraceae (Composite) is a potential oilseed crop for increasing edible oil production in Pakistan. It is a short duration crop and is considered to be a good source of both oil and proteins. Its oil contents range from $40-45 \%$ while its protein content ranges from $38-45 \%$. Sunflower oil contains high contents of oleic, linoleic and linolenic acids. It is considered to be most suitable for margarine production, hydrogenation and as cooking oil. Sunflower is a crop of temperate region but it is adaptable to a wide range of climatic conditions. It thrives in well drained soils. Acidic and Saline soil are also undesirable for its growth, though it can tolerate a $\mathrm{pH}$ range from 6.5-8.0 [1]. Climatic conditions and cropping system of Pakistan warrant the possibility of having two crops of sunflower in a year, spring and 
autumn. Spring crop is more seed yielding than that of autumn crop [2]. Both the crops (spring and autumn) being grown in opposite environmental conditions, all growth, developmental and grain filling phases in various circles of sunflower heads are affected accordingly [3]. In Pakistan sunflower was first introduced as an oil seed crop in the 1960's. Extensive research work on different aspects of this crop has continued since 1964. The cultivated area and production of sunflower in Khyber Pakhtunkhwa (KPK) since 1992-93 to 199697 increased from 6338 to 15444 acres with production of 3326 to 8750 tons respectively [4]. In Pakistan it is cultivated on area of 397,306 ha, with the production of 603,894 tons [5]. It is successfully cultivated in Thatha, Badin, Hyderabad, Mirpur Khas, Tando Allah Yar, Umar Kot and Nawab Shah Districts in Sindh. In Punjab, it is successfully cultivating in the district of Multan, Vehari, Lodhran, Bahawalpur, Bahawal Nagar, Muzafar Garh, Rajan Pur and Layyah. While in KPK, it is grown in D. I. Khan. Average yield at farmer's field is $1520 \mathrm{Kg} \mathrm{ha}^{-1}$, while potential yield at progressive farmer's field is $3800 \mathrm{Kg} \mathrm{ha}^{-1}$. However, potential yield at research station/institute is > $4500 \mathrm{~kg} \mathrm{ha}^{-1}$ [6]. Fertilizer application is an effective method of improving crop yields. Sunflower needs sufficient quantities of plant food nutrients depending upon soil fertility to produce a bumper crop. Our soil has been exhausted due to continuous cultivation without giving proper attention to replenish the plant food nutrients in it. Nitrogen, phosphorus and potash are the major nutrients, which are likely to become deficient in most soils and their application usually results in increased production. Thus the fertilizer NPK plays an important role in boosting up the yield and oil content of sunflower. The production can be further increased by adopting the proper agronomic practise like seed bed preparation, plant protection measures, irrigation, weeding and hoeing etc, but selection of high yielding varieties and use of recommended fertilizer doses have very important role in increasing the production efficiency of sunflower. Therefore this experiment was designed to study the response of sunflower varieties to NPK application in different proportions.

\section{Materials and methods}

The research study was conducted at Agriculture Research Institute (ARI) Tarnab (Peshawar) in order to investigate the "Response of sunflower varieties (hybrids) to different levels of Nitrogen, Phosphorus and Potash (NPK)". The experiment was laid down in two factorial randomized complete block design (RCBD) with 4 replications in a split plot arrangement. Four sun flower (hybrids) varieties (Aritar-93, Peshawar-93, Hysun-33 and SF-187) were sown with five levels of NPK (40:40:40, 80:50:50, 120:60:60, 160:70:70 and 200:80:80 kg ha ${ }^{-1}$ ) making a total of 20 treatments per replication. The fertilizer treatments and varieties were randomized in the main and subplot respectively. The sub plot size was $15 \mathrm{~m} 2$ having 4 rows 5 meter long with $75 \mathrm{~cm}$ apart. The experimental plot was thoroughly prepared before planting. Seed at the rate of $8 \mathrm{~kg} \mathrm{ha}^{-1}$ was sown. The crop was planted $15-20 \mathrm{~cm}$ (P-P distance) apart on ridges and plant population of 50,000 hectare $^{-1}$ was maintained approximately. Half of the $\mathrm{N}$ and all $\mathrm{P}$ and $\mathrm{K}$ were applied at the time of sowing in the form of urea, triple superphosphate (TSP) and potassium sulphate respectively. The remainder half of $\mathrm{N}$ was applied after one month. Soil analysis was performed before sowing and after harvesting. Standard cultural practices were performed throughout the growing season. The data was recorded on plant height $(\mathrm{cm})$, days to maturity, disc diameter $(\mathrm{cm}), 1000$ seed weight $(\mathrm{g})$ and seed yield hectare ${ }^{-1}(\mathrm{~kg}$ 
$\left.\mathrm{ha}^{-1}\right)$. Data was statistically analysed by as per procedure described [7] and means were compared using least significant difference (LSD) test in case of significant differences.

\section{Results and discussion}

Plant height (cm)

Analysis of the data for plant height revealed significant differences due to fertilizer (F) and varieties (V). However, the interaction between $\mathrm{F} \times \mathrm{V}$ had no significant effect. Mean values for fertilizers revealed that plant height increased with increase in fertilizer level (Table 1). The tallest plants $(117.6 \mathrm{~cm})$ were observed in those plots where fertilizer dose of $200-80-80 \mathrm{~kg}$ NPK $\mathrm{ha}^{-1}$ was applied while the shortest plants $(112.2 \mathrm{~cm})$ were noted in plots with a fertilizer dose of 40-40-40 kg NPK ha-1. Mean values for the varieties showed that the tallest plants $(128.6 \mathrm{~cm})$ were noted in Hysun-33, while the shortest plants (102.4 $\mathrm{cm})$ were observed in Peshawar-93. Mean values for the interaction between $\mathrm{F} \times \mathrm{V}$ did not affect significantly the plant height. The experimental results are in line with those of [8] who also reported similar results for the parameter under investigation.

Table 1. Plant height (cm) of sunflower varieties as affected by NPK fertilization

\begin{tabular}{|l|l|l|l|l|l|}
\hline \multirow{2}{*}{$\begin{array}{l}\text { Fertilizer } \\
\text { K }\left(\mathbf{k g ~ h a}^{-1}\right)\end{array}$} & N-P- & Sunflower varieties \\
\cline { 2 - 6 } $\mathbf{4 0 - 4 0 - 4 0}$ & Aritar-93 & Peshawar-93 & Hysun-33 & SF-187 & Mean \\
\hline $\mathbf{8 0 - 5 0 - 5 0}$ & 107.60 & 100.20 & 126.28 & 114.73 & $112.2 \mathrm{~d}$ \\
\hline $\mathbf{1 2 0 - 6 0 - 6 0}$ & 107.85 & 101.00 & 126.95 & 115.85 & $112.9 \mathrm{~cd}$ \\
\hline $\mathbf{1 6 0 - 7 0 - 7 0}$ & 109.7 & 101.25 & 128.60 & 118.18 & $114.4 \mathrm{bc}$ \\
\hline $\mathbf{2 0 0 - 8 0 - 8 0}$ & 111.60 & 103.88 & 130.55 & 118.20 & $116.1 \mathrm{ab}$ \\
\hline Mean & $110.2 \mathrm{c}$ & $102.4 \mathrm{~d}$ & $128.6 \mathrm{~b}$ & $117.6 \mathrm{a}$ & \\
\hline
\end{tabular}

LSD (0.05) Fertilizer $=0.500$ and varieties $=3.179$

Days to maturity

Data regarding days to maturity showed that fertilizer (F) and varieties (V) had significant effect on this parameter (Table 2). However, interaction between $\mathrm{F} \times \mathrm{V}$ showed non-significant effect. Mean values of fertilizer doses revealed that maximum days (90.69) to maturity were taken in plot that received fertilizer dose of $200-80-80 \mathrm{~kg}$ NPK ha ${ }^{-1}$ while minimum days (83.81 days) was recorded with 40-40-40 kg NPK ha-1. Mean values for varieties showed that maximum days (93.30) to maturity were taken by Hysun-33. Minimum number of days $(81.25$ for the trait under investigation was taken by Peshawar-93. Mean values for the interaction between $\mathrm{F} \times \mathrm{V}$ showed nonsignificant effect on days to maturity. The findings of the experiment are in agreement with the results of [9].

Table 2. Days to maturity of sunflower varieties as affected by NPK fertilization

\begin{tabular}{|l|l|l|l|l|l|}
\hline \multirow{2}{*}{$\begin{array}{l}\text { Fertilizer } \\
\text { K }\left(\mathbf{k g ~ h a}^{-1}\right)\end{array}$} & \multicolumn{5}{|c|}{ Sunflower varieties } \\
\cline { 2 - 6 } $\mathbf{4 0 - 4 0 - 4 0}$ & Aritar-93 & Peshawar-93 & Hysun-33 & SF-187 & Mean \\
\hline $\mathbf{8 0 - 5 0 - 5 0}$ & 79.25 & 77.50 & 90.25 & 88.25 & $83.81 \mathrm{~d}$ \\
\hline $\mathbf{1 2 0 - 6 0 - 6 0}$ & 82.25 & 79.50 & 91.75 & 90.25 & $85.94 \mathrm{~cd}$ \\
\hline $\mathbf{1 6 0 - 7 0 - 7 0}$ & 82.75 & 81.00 & 93.75 & 92.75 & $87.56 \mathrm{bc}$ \\
\hline $\mathbf{2 0 0 - 8 0 - 8 0}$ & 85.00 & 83.50 & 94.50 & 93.50 & $89.13 \mathrm{ab}$ \\
\hline Mean & 85.25 & 84.75 & 96.25 & 96.50 & $90.69 \mathrm{a}$ \\
\hline
\end{tabular}

LSD (0.05) Fertilizer $=2.652$ and varieties $=1.879$ 


\section{Disc diameter (cm)}

Data pertaining fertilizer $(\mathrm{F})$ and varieties (V) showed significant effect on disc diameter (Table 3). However, the interaction between fertilizer treatment and varieties $(\mathrm{F}$ $\times V)$ had non-significant effect on disc diameter. Mean values for fertilizer levels showed that maximum disc diameter of $(20.61 \mathrm{~cm})$ was observed in the plots which received NPK dose at the rate of 200-80-80 $\mathrm{kg} \mathrm{ha}^{-1}$ followed by plots $(20.11 \mathrm{~cm})$ which received NPK dose at the rate of 160-70-70 $\mathrm{kg} \mathrm{ha}^{-1}$. However, minimum disc diameter of $(18.18 \mathrm{~cm})$ was measured in those plots which received NPK levels at rate of 40-40$40 \mathrm{~kg} \mathrm{ha}^{-1}$. The mean of fertilizer levels revealed that disc diameter increased with increase in fertilizer level. Mean values of the varieties showed that maximum disc diameter $(21.58 \mathrm{~cm})$ was observed for variety SF-187, while minimum $(16.98 \mathrm{~cm})$ was noted for Peshawar-93. Mean values for the interaction between $\mathrm{F} \times \mathrm{V}$ showed that maximum disc diameter $(23.10 \mathrm{~cm})$ was observed in case of variety SF-187 for a fertilizer dose of 200-80-80 kg NPK ha ${ }^{-1}$, while minimum disc diameter $(16.03 \mathrm{~cm})$ was noted for Peshawar-93 that received 4040-40 kg NPK ha-1. Our results are fully supported by $[10,11]$ who also reported that head diameter is increasing with increased dose of NPK.

Table 3. Disc diameter $(\mathrm{cm})$ of sunflower varieties as affected by NPK fertilization

\begin{tabular}{|l|l|l|l|l|l|}
\hline \multirow{2}{*}{$\begin{array}{l}\text { Fertilizer N-P-K } \\
\left(\text { kg ha- }^{-1}\right)\end{array}$} & \multicolumn{5}{|c|}{ Sunflower varieties } \\
\cline { 2 - 6 } & Aritar-93 & Peshawar-93 & Hysun-33 & SF-187 & Mean \\
\hline $\mathbf{4 0 - 4 0 - 4 0}$ & 18.05 & 16.03 & 18.38 & 20.28 & $18.18 \mathrm{~d}$ \\
\hline $\mathbf{8 0 - 5 0 - 5 0}$ & 18.38 & 16.58 & 19.80 & 20.48 & $18.81 \mathrm{~cd}$ \\
\hline $\mathbf{1 2 0 - 6 0 - 6 0}$ & 18.95 & 17.00 & 20.50 & 21.78 & $19.56 \mathrm{bc}$ \\
\hline $\mathbf{1 6 0 - 7 0 - 7 0}$ & 19.13 & 17.58 & 21.50 & 22.25 & $20.11 \mathrm{ab}$ \\
\hline $\mathbf{2 0 0 - 8 0 - 8 0}$ & 19.78 & 17.73 & 21.83 & 23.10 & $20.61 \mathrm{a}$ \\
\hline Mean & $18.86 \mathrm{c}$ & $16.98 \mathrm{~d}$ & $20.40 \mathrm{~b}$ & $21.58 \mathrm{a}$ & \\
\hline
\end{tabular}

LSD (0.05) Fertilizer $=0.8834$ and varieties $=0.7606$

\section{0 seed weight $(\mathrm{g})$}

Data concerning fertilizer $(\mathrm{F})$ and varieties (V) revealed that fertilizer doses and varieties had a significant effect on thousand grain weight (Table 4). However the interaction between $\mathrm{F} \times \mathrm{V}$ had no significant effect on thousand grain weight. The data given in the Table for fertilizer levels showed that maximum thousand grain weights $(47.45 \mathrm{~g})$ was observed in plots that received 200-80-80 kg NPK ha-1 . Minimum thousand grain weight $(43.38 \mathrm{~g})$ was observed in plots that received $40-40-40 \mathrm{~kg}$ NPK ha- ${ }^{-1}$. It is clear from the Table 4 that mean values of varieties were different from each other. The maximum weight of thousand grains $(51.01 \mathrm{~g})$ was noted for the plots of variety SF-187, while minimum weight of thousand grains (40.49 g) was calculated for variety Peshawar-93. It is evident from the interaction between $\mathrm{F} \times \mathrm{V}$ that maximum weight of thousand grains $(53.23 \mathrm{~g})$ was noted for variety SF-187 which received NPK level at the rate of 200$80-80 \mathrm{~kg} \mathrm{ha}^{-1}$. Minimum weight of thousand grain (38.63 g) was noted Peshawar-93 variety that were given NPK dose at the rate of $40-40-40 \mathrm{~kg} \mathrm{ha}^{-1}$. 
Table 4. Thousand seed weight (g) of sunflower varieties as affected by NPK fertilization

\begin{tabular}{|l|l|l|l|l|l|}
\hline \multirow{2}{*}{$\begin{array}{l}\text { Fertilizer N-P- } \\
\text { K (kg ha }\end{array} \mathbf{~}^{-1}$ ) } & \multicolumn{5}{|c|}{ Sunflower varieties } \\
\cline { 2 - 6 } & Aritar-93 & Peshawar-93 & Hysun-33 & SF-187 & Mean \\
\hline $\mathbf{4 0 - 4 0 - 4 0}$ & 40.65 & 38.63 & 45.20 & 49.03 & $43.38 \mathrm{~d}$ \\
\hline $\mathbf{8 0 - 5 0 - 5 0}$ & 40.90 & 39.63 & 45.38 & 50.10 & $44.00 \mathrm{~cd}$ \\
\hline $\mathbf{1 2 0 - 6 0 - 6 0}$ & 41.60 & 39.95 & 46.30 & 50.65 & $44.63 \mathrm{bc}$ \\
\hline $\mathbf{1 6 0 - 7 0 - 7 0}$ & 43.05 & 41.98 & 47.85 & 52.08 & $46.24 \mathrm{ab}$ \\
\hline $\mathbf{2 0 0 - 8 0 - 8 0}$ & 44.43 & 42.25 & 49.90 & 53.23 & $47.45 \mathrm{a}$ \\
\hline Mean & $42.13 \mathrm{c}$ & $40.49 \mathrm{~d}$ & $46.92 \mathrm{~b}$ & $51.01 \mathrm{a}$ & \\
\hline
\end{tabular}

LSD (0.05) Fertilizer $=2.049$ and varieties $=1.938$

\section{Grain yield (Kgha-1)}

Data recorded on grain yield in $\left(\mathrm{Kg} \mathrm{ha}^{-1}\right)$ is presented in Table 5. Analysis of the data revealed that fertilizer $(\mathrm{F})$ and varieties $(\mathrm{V})$ had significant effect on grain yield. However, the interaction between $\mathrm{F} \times \mathrm{V}$ had non-significant effect on grain yield. Mean values for fertilizer levels showed that maximum grain yield of $\left(1324 \mathrm{~kg} \mathrm{ha}^{-1}\right)$ was recorded in those plots which received fertilizer level of 200-80-80 kg NPK ha-1, followed by grain yield of $\left(1285 \mathrm{~kg} \mathrm{ha}^{-1}\right)$ from plots that received fertilized by 160 $70-70 \mathrm{~kg}$ NPK ha- ${ }^{-1}$ Minimum grain yield (991.7 $\mathrm{kg} \mathrm{ha}^{-1}$ ) was observed in those plots that received fertilizer level of $40-40-40 \mathrm{~kg}$
NPK ha ${ }^{-1}$. Data given in (Table 5) for varieties showed that maximum grain yield (1408 $\mathrm{kg} \mathrm{ha}^{-1}$ ) was recorded for variety Hysun-33. Similarly minimum grain yield $\left(947.6 \mathrm{~kg} \mathrm{ha}^{-1}\right)$ was noted for variety Peshawar-93. Interaction between $\mathrm{F} \times \mathrm{V}$ showed that maximum grain yield (1584.75 $\mathrm{kg} \mathrm{ha}{ }^{-1}$ ) was recorded in those plots of variety SF-187 that received $200-80-80 \mathrm{~kg}$ NPK ha ${ }^{-1}$, followed by $\left(1545.24 \mathrm{~kg} \mathrm{ha}^{-1}\right)$ in those plots of variety SF-187 that received a fertilizer dose of $160-70-70 \mathrm{~kg}$ NPK ha ${ }^{-1}$, while minimum grain yield $\left(787.53 \mathrm{~kg} \mathrm{ha}^{-1}\right)$ was recorded in those plots of variety Peshawar-93 that received 40-40-40 kg NPK $\mathrm{ha}^{-1}$.

Table 5. Grain yield (kg ha-1) of sunflower varieties as affected by NPK fertilization

\begin{tabular}{|l|l|l|l|l|l|}
\hline \multirow{2}{*}{$\begin{array}{l}\text { Fertilizer N- } \\
\text { P-K }\left(\text { kg ha }^{-1}\right)\end{array}$} & \multicolumn{4}{l|}{ Sunflower varieties } & \\
\cline { 2 - 6 } & Aritar-93 & Peshawar-93 & Hysun-33 & SF-187 & Mean \\
\hline $\mathbf{4 0 - 4 0 - 4 0}$ & 886.73 & 787.53 & 1071.68 & 1220.90 & $991.7 \mathrm{c}$ \\
\hline $\mathbf{8 0 - 5 0 - 5 0}$ & 938.35 & 875.20 & 1141.65 & 1290.40 & $1061.0 \mathrm{c}$ \\
\hline $\mathbf{1 2 0 - 6 0 - 6 0}$ & 992.52 & 989.20 & 1227.58 & 1400.57 & $1152.0 \mathrm{~b}$ \\
\hline $\mathbf{1 6 0 - 7 0 - 7 0}$ & 1117.52 & 1066.85 & 1412.05 & 1545.24 & $1285.0 \mathrm{a}$ \\
\hline $\mathbf{2 0 0 - 8 0 - 8 0}$ & 1208.17 & 1019.40 & 1482.53 & 1584.75 & $1324.0 \mathrm{a}$ \\
\hline Mean & $1029.0 \mathrm{c}$ & $947.6 \mathrm{~d}$ & $1267.0 \mathrm{~b}$ & $1408.0 \mathrm{a}$ & \\
\hline
\end{tabular}

LSD $(0.05)$ Fertilizer $=71.88$ and varieties $=81.59$

\section{Conclusion and recommendations}

Based on this experiment it is concluded that yield and other yield contributing traits of sunflower varieties improved with NPK fertilization, however the performance of hybrids SF-187 and Hysun-33 was more prominent at $200-80-80 \mathrm{~kg} \mathrm{NPK} \mathrm{ha}^{-1}$. It is suggested to apply NPK at the rate of 200$80-80 \mathrm{~kg} \mathrm{ha}^{-1}$ to hybrids SF-187 and Hysun33 for obtaining good yield of sun flower.

Authors' contributions

Conceived and designed the experiments: F Mohammad, Performed the experiments: I Ahmad \& SA Jadoon, Analyzed the data: A 
Said, Contributed reagents/ materials/ analysis tools: A Said \& M Adnan, Wrote the paper: F Munsif.

\section{References}

1. Hatim M \& Abbasi GQ (1994). Oilseed crops. In Crop Production. National Book Founation, Islamabad Pakistan.

2. Qadir G, Hassan FU \& Malik MA (2007). Growing degree days and yield relationship in Sunflower (Helianthus annuus L.). Int J Agric \& Biol 9: 564-568.

3. Shuaib K \& Fayyaz H (2010). Seed and oil distribution in different circles of mature sunflower head. Pak J Bot 42(5): 30053014.

4. PODB (1997). Oil seed production for 1996-97. Ministry of food, livestock and Agriculture, Government of Pakistan, Islamabad.

5. Anonymous (2008-09). Agricultural Statistic of Pakistan. Ministry of Food, Agriculture and Livestock. Govt. Pakistan, Islamabad. pp. 65.

6. Arshad M, Khan MA, Jadoon SA \& Mohammad AS (2010). Factor Analysis in sunflower (Helianthus annuus L.) to investigate desirable hybrids. Pak $J$ Bot 42(6): 4393-4402.

7. Steel RD \& Tore JH (1960). Principles and Procedures of Statistics. McGraw-Hill, Toronto, $481 \mathrm{pp}$.

8. Nur IM (1974). Sunflower response to nitrogenous fertilization at G.R.S. Acta Agronomica. 24(3-4): 463-466. Ciba Gaigy ten. Khartoum. Sudan. Soil and Fert. 39(6):4399. Field Crop Abstracts 29(11): 5387, 1976.

9. Bakhat J, Khalil SK, Shah Z, Ehsanullah \& Qayyum A (1989). Yield and yield components of maize and sunflower sown alone and in different combinations under various nitrogen levels. Sarhad J Agric 5: 101-6.

10. Bamdad DJ (1972). Effect of NPK ratio application rate on sunflower seed yield and other characteristics. Proceeding of $5^{\text {th }}$ international conference on sunflower. 2529 July, 1972.

11. Zubriski JG \& Zimmermann DC (1974). Effect of nitrogen, phosphorus and plant density on sunflower. Agron J 66(6): 798801. Soil and Fert Abstracts 38(8): 3151. 